\title{
Promoting Passion-Based Learning as a Solution of Improving Creativity in English Classroom
}

\author{
Bulqia Mas'ud ${ }^{1}$, Achmad Taqlidul Chair Fachruddin ${ }^{2}$, Syamsinar $^{3}$ \\ Tarbiyah and Teaching Training Department, State Islamic College of Majene ${ }^{123}$ \\ bulqia@stainmajene.ac.id ${ }^{1}$, achmad.taqlidul@stainmajene.ac.id ${ }^{2}$ \\ syamsinar@stainmajene.ac.id ${ }^{3}$
}

\begin{abstract}
This article investigates a pedagogical interference in promoting creativity in English classroom that describe the importance of creativity in learning process. The article explores the idea of passion-based learning in improving creativity in the classroom specially in English subject. By using secondary data both from journals, books, and internet sites, researcher is able to apply descriptive analysis through literary review methods. Promoting passion-based learning might be a possible way to improve creativity in English Classroom. Passion-based learning could be a solution that give ownership and authority to students to explore their own creativity in the classroom hence give them meaningful learning. Some tangible ways in this article could be applied by English teachers to create passion-based learning in English classroom that can improve the students' reading, listening, speaking and writing skill and creativity. The emerging challenge found in this study is passion-based learning is difficult to apply in large class since it gives freedom to students choose what they want to learn hence classroom activities will not be feasible to control. Besides, passionbased learning needs creative and skilful teachers to come up with various and interesting ideas to stimulate dynamic in classroom. Therefore, the quality of teacher is highly considered in applying passion-based learning. Teachers should be expert in subjects they teach. Promoting teacher professional development need to be considered to improve creativity in English classroom with given English teachers' opportunities to explore their potentials.
\end{abstract}




\section{Introduction}

Teaching foreign language needs creativity to engage students. Classroom activities will determine the learning engagement of the students. Lack of classroom interest could be the impediments to acquire meaningful learning process. Hence, teachers as facilitators of learning are expected to provide various ways to improve students' creativities. Besides, teachers' engagements sometimes become problems that contribute to the lack of classroom interest. In order to develop the teaching engagement of English as a foreign language (EFL) for teachers encountered in the situation, creative ways considered as advantageous ways are needed in this pedagogical activities.

English educators nowadays face many challenges to keep up with the recent $21^{\text {st }}$ learning skill that should be taught in any educational context. The English classroom also need creativity since the subjects aimed to facilitate students to be lifelong learners. A rising discussion about the nature of lifelong learning and the various skill and attitude are important in students' pathfinding after graduating (Craft, 1998). The sense of nurturing creativity across curriculum is arguably needed. Craft (1998) also argued that creative teaching should be able to identify students' needs distinctly and able to read a situation, ability to take a risk and capacity in supervising and monitoring students and evaluating students' experiences and outcomes. Besides, creative teaching discourse both teachers' and students' ownership, control and innovation in the classroom (Woods, 1990, cited in Craft, 1998).

The role of authority owned by the teacher considerably affects students' knowledge acquisition process (Burns \& Richards, 2009 cited in Avila, 2015). Consequently, the creativity is a means of exploring classroom activities to involve the students in order to achieve their maximum potential and meaningful learning. In other words, a teacher's creativity could stimulate her/his students' creativity both inside and outside of the classroom. However, effective learning process could not be achieved if all classroom responsibilities assigned to teachers alone. Learner creativity is also need in creating meaningful learning. Learners creativity could be learned from their unique intelligence. Gardner (1993) has 
proposed various creativity in his theory of multiple intelligence. By studying this different intelligence, teachers could determine their students' passion in learning.

This paper will see the gap between lack of creativity in classroom and possible solution to overcome the problem. Focusing on students' passion could be one of ways to explore students' creative skills. When learning passionately, students have chances to going deep into themselves and digging the hidden potentials since they are not forced to master all the materials instead focus on what is interested to them. Passion-based learning might be the possible solution to solve students' lack of creativity in the classroom. In addition, this research will focus on English classroom both in secondary school and higher education. The researcher will further describe the link between creativity and education and how passion-based learning could solve the problem of students' lack of creativity in English classroom.

\section{Methods}

This paper uses qualitative research with descriptive analysis. This approach has been very common procedures for conducting research in many disciplines, including education. Nassaji (2015) argued that this method is increasingly used in the field of second language teaching and learning. He added "The goal of descriptive research is to describe a phenomenon and its characteristics" (Nassaji, 2015, pg. 129).

A literature review is used to gain secondary data from books, academic journals and blogs that address the topic. To answer the research questions, a literature review might be the best method to provide answers. According to Tranfield et al., (2003) cited in Syned (2019) literature reviews are suitable when the researcher wants to assess theories. Literary review used in this research is to investigate the effect of relationship between two specific variables which are passion-based learning and creativity in English classroom. Moreover, literature reviews are beneficial when the purpose of the paper to provide an overview of a certain issue or research problem (Syned, 2019). Hence, this type of literature review is conducted to evaluate the state of knowledge on a particular topic. 
More importantly, this method will open the potential for making theoretical and practical aids using the literature review as a method and will be progressed by expounding how it can be used and what principles should be used to evaluate its quality (Syned, 2019).

\section{Creativity in Education}

To be able to solve problems, teachers should use creative and innovative ways to also arise student creativity. One of responsibilities of a school is ensuring creativity explored in class to develop students' capabilities. According to Naiman (1998) cited in Avila (2015), creativity is the process of using imaginative ideas into reality. This author believes that creativity consist of two kinds of processes: thinking and producing. Furthermore, it could be said that creativity is running in our mind and waiting to be awaken. Each person actually has creativity because it can be developed as Balkin (1990) argued creativity is not a synonym for talent. "Creativity, on the other hand, is an acquired behavior-learnable, teachable, tangible, and crucial to human development" (Balkin, 1990 p.29). Since creativity is teachable, school system must take it into account to promote creative learning in the classroom.

One of ways that could be done to promote creativity in the classroom is applying discovery and inquiry learning or problem-solving approach (Fasko, 2000). Trefingger stated that "experience with discovery learning enhances creative performance by forcing the learner to manipulate the environment and produce new ideas" (1980, p. 34). As a result, teachers should direct their student in the learning environment that could increase creativity as stated by May (1994) creativity is the process of bringing something new to the culture and environment and entails passion and commitment. Both teachers and students must aware that creativity should be brought in the classroom. Therefore, teachers should apply creative teaching in their classroom.

Torrance (1981) cited in Fasko (2000) argued that the aims of creative teaching is to create a responsible environment through high teacher enthusiasm, 
appreciation of individual differences. This idea is also supported by Davis (1991) who thought designing a "creative climate" was important to stimulate creative thinking. Fasko (2000) provided several recommendations for establishing a classroom environment conducive to creative thinking with using an inquiry-discovery as followed:

1. Provide the initial experience to interest students in inquiring about a problem, concept, situation, or idea.

2. Provide the students with manipulative situations and materials to begin avenues of exploration.

3. Supply information sources for students' questions.

4. Provide materials and equipment that will spark and encourage student experimentation and production.

5. Provide time for students to manipulate, discuss, experiment, fail, and succeed.

6. Provide guidance, reassurance, and reinforcement for student ideas and hypotheses.

7. Reward and encourage acceptable solution strategies. A supportive positive climate will spawn the best results (Fasko, 2000 p.321).

In order to have an in-depth understanding of the creativity term, Csikszentmihalyi (2013) cited in Avila (2015) describes five steps to achieve creativity:

1. Preparation: Arousing curiosity of a problematic situation.

2. Incubation: Ideas fly below the threshold of consciousness.

3. Insight: The moment when the puzzle starts to fall together.

4. Evaluation: Deciding if the insight is valuable and worth pursuing

5. Elaboration: Translating the insight into its final work. (p. 94)

These steps are very important to guide teachers to improve creativity in 
their classroom. The whole process involves teachers to explore and demonstrate innovative and imaginative ideas to be worth implemented. Those process are very insightful to school system in preparing supported environment for both teachers and students. In brief, it is not possible that educators can teach creativity in their classroom.

Implementing appropriate approach in inciting creativity in the classroom is also aligned with the policy of current curriculum which gives autonomy to school to arrange their own structure and curriculum contents. Teachers then could apply creative method when teaching. Students need to be given freedom to choose material they love to learn. Schools and teachers should liberate students to determine their own way of learning. This is the idea behind passionbased learning where students are passionate about what they learn, not stressful and always happy and joyful.

\section{Understanding Passion-Based Learning}

Since passion-based learning is a new term, I will explain the definition clearly. Passion is not a new word in our lives. It is very familiar since it is very important to have it. People might have different opinion with definition of passion according to any field they are engaging in and it is essential to own it as a learner. Passion-based learning is a new method of teaching and learning proposed by some educators and practitioners. They discuss more about passionbased learning in education websites. As writing this essay, I still do not find many refereed article journals discussing this topic hence it is really urgent to research this method for educational development. The ideas around this topic mainly discussed in professional education websites.

Passion-based learning is a love of learning which to keep the embers of passion for learning alive (Ramirez, 2013). Passion-based learning covers two things which are finding out what students innately passionate about and be an instructor that exude passion for the topic, and ignite students with excitement (Ramirez, 2013). Thus, in passion-based learning, we do not only need students' engagement, but also teachers' engagement. 
In addition, passion-based learning is more self-directed learning (andragogy) as Knowles (1975, p.18) cited in Blaschke (2012) defined as "a process in which individuals take the initiative, with or without the help of others, in diagnosing their learning needs, formulating learning goals, identifying human and material resources for learning, choosing and implementing appropriate learning strategies, and evaluating learning outcomes". However, teachers' role in managing the class is still necessary. Teachers can act as facilitators and observers. They let students come up with something they are really passionate about that can be related to the curriculum and allow them to work within that space (Nussbaum-Beach, 2011). Therefore, the collaboration between teachers and students can create positive learning environment to ease students acquire knowledge and skills.

Brown and Adler (2008) defined passion-based learning as a new form of learning begins with the knowledge and practices acquired in school but is equally suited for continuous, lifelong learning that extends beyond formal schooling. Furthermore, this might encourage students to readily and happily pick up new knowledge and skills as they like (Brown and Adler, 2008). Even though students are taught how to pick up skill earlier, this idea seems preparing to students to enter capitalist industry as Maiers (2011) said that passion-based learning is about finding a "hero" who can makes him/her successful acquiring the practice of established practitioners in the chosen field. When students could acquire earlier skills, schools can be taken advantage by market industry to produce many young workers that are ready to work. As a result, they might be exploited in their young age. Nevertheless, teaching students to develop skill that suit to students' passion is essential. Having passion can be very influential in students' learning process such as arising creativity.

Another name of passion-based learning is genius hour which is defined by (Kesler, 2013) as giving students freedom to explore their passion and promote creativity in classroom. Genius hour engages students in open inquiry where teachers explain the knowledge framework yet the inquiry will be conducted by students and allow them to design or choose questions or knowledge they would 
like to inquire (Zion \& Mendelovici, 2012). In addition, ”open inquiry does not separate teaching from learning, but creates a learning community of teachers and students that is crucial to the success of the inquiry process (Zion \& Slezak, 2005 cited in Zion \& Mendelovici, 2012, p.2).

\section{Passion-Based Learning as a Solution of Improving Creativity in English Classroom}

Since lack of creativity brings some negative effects on learning process of students, this paper will try to offer a possible solution. However, my investigation proposes to take a possible way how to reduce the impacts of lack of creativity in the classroom hence the creative teaching and learning could be implemented easily, meaningfully, and no longer perceived difficult. Therefore, by applying passion-based learning in the classroom, we can prevent students from stress, yet boost their motivation, apply deep learning and appreciate individual differences. Since this method is closely related to inquiry-based learning, it is very suitable to apply in every classroom.

Passion-based learning could avoid students from stress and frustration and improve their imaginative minds. In passion-based learning, students learn and pick material they are passionate about in specific element of curriculum (Nussbaum-Beach, 2011). Students are given freedom to organize their own learning. School provides tools and teachers facilitate the learning process, while observe children learn creatively. Teachers should know their students' passion and show how the materials suit to their passion. In addition, students do not have to learn the same material. As the idea of passion-based learning is picking knowledge that students want to master, they can choose what they want to master in the subject taught that day. Hence, the concept of learning is designed joyful as students want.

Lack of creativity in classroom hamper students to deep learning. Passionbased learning is the possible way to make students learn deeply. When students love what they learn, they will try to find out in details and depth what makes 
them really interested in. They will keep searching, finding, and asking until they find the correct answer. Students are engaged in problem-solving and decisionmaking process which demand questioning, critical and logical thinking, also demonstrate ownership and responsibility for determining the aims of the investigation (Zion \& Mendelovici, 2012). This will lead them to understand the subject well and deeply.

Passion-based learning also give choices to students to pick specified material they would like to learn and skill they want to master hence individual differences are highly appreciated. Students will be not forced by teachers to master all materials. In contrast, teachers should show the way how students be problem solvers in their lives with skills they have. By applying passion-based learning, teachers can cover curriculum with more engaging and effective way. They can explore uniqueness of each student. Thus, teachers become know what students like, dislike, and struggle. Moreover, they could implement curriculum which suits to their students' need. In short, teachers could help students to explore their interest, make decision, and practice their skill in area of curriculum.

\section{Passion-Based Learning in Improving Reading Skill}

In English reading classroom specially for secondary school, teacher could implement passion-based learning by liberating students to choose what they want to read. Teachers could ask their students to pick one reading either fiction or nonfiction that are most attractive to them. Beside inciting the love of reading, students also can learn grammar and vocabulary through books that they like the most. Focusing on one favourite book will give students enjoyment in learning and exploring vocabularies. Teachers could direct students to underline their favourite dialogue in the reading and asses the grammar used and find new vocabularies. Beside underlining, students could also re-write the most interesting sentences and dialogue and analyse the grammatical rules each sentence or dialogue. Also, they can pick the new vocabularies and apply them in difference sentences and contexts. This idea might develop creative thinking of the students and create joy in their learning process. 
Passion-Based Learning in Improving Listening Skill

The exercises in listening classroom might be designed to let students listening joyfully and meaningfully with focus and their passions. Students are asked to pick videos on YouTube based on their preference. They might choose English songs, movie, or English talks. By studying the videos, students are asked to discover voices that are difficult to understand. They can replay the videos using their own devices. They can also pick and learn new vocabularies such as idioms, expressions, and other difficult words. Furthermore, they could also analyze the grammatical rules applied in the videos and identify incorrect grammar that might be found in the videos. These activities could improve their creativity to learn grammar rules in fun ways.

\section{Passion-Based Learning in Improving Speaking Skill}

In order to practice speaking teacher might ask students to draw something they want to share. Teachers should make sure students choose topic that is interesting for them. The students must draw it on the board and explain the story behind the drawing. This activity is done interchangeably. Students are given turn and present their own drawing. In addition, teacher could also do this activity in group. Teachers might create some groups in the class. In each group, the first student would come up and draw something. After that, another student is assigned to draw another object. After all the participants drew their objects, they would have to create a story based on the drawings on the board.

By applying this activity, students will have the opportunity to share their stories with others and evaluate their own process with peer-correction and assessment. They will have more autonomy in their own drawings and encourage confidence while speaking to their friends. This activity will promote students' creativity since the students have the challenge to create a story with those drawings which proved to be joyful and meaningful.

Hence, this passion-based learning activity gives students autonomy to communicate their feelings and imagination through the exercises and develop 
their thinking and enhance their abilities in the target language by speaking topics that are attracted to them.

\section{Passion-Based Learning in Improving Writing Skill}

Practicing creative writing to promote creativity English classroom might be beneficial. Creative writing can be used as an instrument to improve students' feelings towards writing. Some research said that creative writing enables students to transfer out words, imagination, obtain understanding of accuracy and most importantly experience the joy of learning a foreign language (Amado, 2010 cited in Avila, 2015). In addition, teaching creative writing is thought to be easier since it can prevent writer's block when the writing is flowing creatively.

Avila in her research (2015) apply this creativity. Teachers could divide students into two or three groups. Teachers give one opening sentence to each group. Then each group has five minutes to write a story and then give it to their partners to continue writing about the same theme and complete the story. The group who have the best story with the appropriate grammar and interesting idea will have higher point. Students are given their ownership and creativity to sail on their own imagination, create their own fictional worlds. All in all, designing creative activities offers students the opportunity to develop their creative potential and to produce knowledge and skills by creating and participating in the teaching process (Avila, 2015).

\section{The Challenges}

Nowadays, Indonesia is still implementing the curriculum 2013 as the response of failure of curriculum 2006 in enhancing students' achievement in science competition (Widarsa, 2012). The criticism coming from many experts which argue that teaching practice in Indonesia is less creative and does not apply discovery and inquiry-based learning. Teacher competence should be improved, and the culture of loving learning should be grown. Hence, schools, teachers, and other stakeholders should create positive learning environment that make students more engaging. It is also important to know the possible impact and challenge 
behind the idea of passion-based learning. As it aims to prepare students for the $21^{\text {st }}$ century (Ramirez, 2011), education is regarded now as an international commodity in the context of globalization, playing a remarkable mission in the global economy with investment in people, skills and knowledge (Al' Abri, 2011). Besides, as it is very new method in Indonesia context, it might meet some impediments.

Firstly, large classes in Indonesia's schools are ubiquitous since Indonesia has a big population. Passion-based learning is more suitable to classes that contains small number of students so that teachers could easily observe their students. In passion-based learning, teachers should supervise their students' developments when doing passionate inquiry and learning. So, it will be difficult to handle a large class with students who might have various passion. The learning will not run effectively. Otherwise, if the class is managed by two or three teachers who also have different skills, hence they can group students based on similar interest.

Secondly, passion-based learning needs skilful teachers who should be passionate about teaching. Before guiding students to master their skill, they should master the skill first. Teachers should understand deeply what they teach before directing students. Therefore, it is very important to measure the readiness of teachers in Indonesia. The quality of teacher is highly considered in applying passion-based learning. Teachers should be expert in subjects they teach. In addition, since it is new method that has only been applied in western countries, we should think how to match teachers' capabilities with the method. It might need longer adaptation to this new method of teaching and learning.

\section{Conclusion}

Promoting passion-based learning in secondary school and possible in higher education could help to improve creativity in English classroom. Lack of creativity when learning could be solved with this method because the learning concept comes from passion which creates enthusiasm. Their engagement is joyful not forceful hence there is no such a pressure when learning. Besides, 
students can understand the subject well because they focus on deep learning which provides students opportunity to investigate the materials they are passionate about. Moreover, it will give students freedom to learn what they want, help them to grow their passion thus it could enhance their motivation to keep learning. As a result, boredom in classroom could be minimised by applying passion-based learning.

Nonetheless, we will not know the result of this solution until school administrators, practitioners and teachers collaborate to implement it. Another investigation such as promoting teacher professional development might be possible solutions need to be considered to improve creativity in English classroom with given English teachers' opportunities to explore their potentials. Moreover, applying passion-based learning could help teachers and school to manage classroom more creatively and effectively. Besides, schools and teachers need to design their own curriculum which can be adjusted to be relevant to students' daily lives and passion. It will also create a love of learning wherever and whenever they are. Since this is a new method of teaching and learning, I highly encourage teachers and educators especially in Indonesia to sound and explore this topic more.

\section{References}

Al'Abri, K. (2011). The impact of globalization on education policy of developing countries: Oman as an example. Literacy Information and Computer Education Journal, 2(4), 491-502.

Avila, H. A. (2015). Creativity in the English Class: Activities to Promote EFL Learning. How, 22(2), 91-103. https://doi.org/10.19183/how.22.2.141

Balkin, A. (1990). What is creativity? What is it not?. Music Educators Journal, 76(9), 29-32.

Blaschke, L. M. (2012). Heutagogy and lifelong learning: A review of heutagogical practice and selfdetermined learning. International Review of Research in Open and Distance Learning, 13(1) Retrieved September 1, 2015 from http://search.proquest.com/docview/1634474130?accountid=12528 
Brown, J. S., \& Adler, R. P. (2008). Minds on fire: Open education, the long tail, and learning 2.0. EDUCAUSE Review, 43(1), 16-20.

Craft, A. (1998). Educator perspectives on creativity: An english study. Journal of Creative Behavior, 32(4), 244-257. https://doi.org/10.1002/j.2162$\underline{6057.1998 . t b 00820 . x}$

Davis, G. A. (1991). Teaching creativity thinking. In N. Colangelo \& G. A. Davis (Eds.), Handbook of gifted education (pp. 236-244).

Fasko, D. (2000). Education and creativity. Creativity Research Journal, 13(3-4), 317-327. https://doi.org/10.1207/s15326934crj1334_09

Gardner, H. (1993). Seven creators of the modern era. Creativity, 28-47.

Kesler, C. (2013). What is genius hour?. Retrieved October 20, 2015 from http://www.geniushour.com/what-is-genius-hour/

Maiers, A. (2011). Guidelines of Passion-Based Learning. Retrieved 31 August, 2015 from http://www.angelamaiers.com/2011/07/guidelines-of-passionbased-learning/

May, R. (1994). The courage to create. New York, NY: W. W. Norton \& Company. Naiman,

Nassaji, H. (2015). Qualitative and descriptive research: Data type versus data analysis. Language Teaching Research, 19(2), 129-132. https://doi.org/10.1177/1362168815572747

Nussbaum-Beach, S. (2011). Passion-based learning for the $21^{\text {st }}$ century. Retrieved October 20, 2015 from http://www.edweek.org/tm/articles/2011/04/20/interview_nussbaumbeach.html

Ramirez, A. (2013). Passion-based learning. Retrieved 31 August, 2015 from http://www.edutopia.org/blog/passion-based-learning-ainissa-ramirez

Snyder, H. (2019). Literature review as a research methodology: An overview and guidelines. Journal of Business Research, 104(July), 333-339. https://doi.org/10.1016/j.jbusres.2019.07.039

Treffinger, D. J. (1980). Encouraging creative learning for the gifted and talented. Ventura, CA: Ventura County Schools/LTI

Widarsa, A. N. (2013, January 03). Leveraging Indonesian educational system. Jakarta Globe. Retrieved August 19, 2015 from 
7nspiring: English Education Journal

Volume 2 No 2 September 2019

http://jakartaglobe.beritasatu.com/archive/leveraging-indonesianeducational-system/

Zion, M., \& Mendelovici, R. (2012). Moving from Structured to Open Inquiry: Challenges and Limits. Science Education International, 23(4), 383-399. 